\title{
Dynamics of Heterocapsa circularisquama (Dinophyceae) and its viruses in Ago Bay, Japan
}

\author{
Keizo Nagasaki ${ }^{1, *}$, Yuji Tomaru ${ }^{1}$, Katsuyuki Nakanishi ${ }^{2}$, Naotsugu Hata ${ }^{2}$, \\ Noriaki Katanozaka ${ }^{3,4}$, Mineo Yamaguchi ${ }^{1}$ \\ ${ }^{1}$ National Research Institute of Fisheries and Environment of Inland Sea, 2-17-5 Maruishi, Ohno, Saeki, Hiroshima 739-0452, Japan \\ ${ }^{2}$ Mie Prefectural Science and Technology Promotion Center, 3564-3 Hamajima, Hamajima, Shima, Mie 517-0404, Japan \\ ${ }^{3}$ SDS Biotech K.K., 2-1 Midorigahara, Tsukuba, Ibaraki 300-2646, Japan \\ ${ }^{4}$ Present address: Hitec Co. Ltd., 1-8-30 Tenmabashi, Kita, Osaka 530-6025, Japan
}

\begin{abstract}
To examine the relationship between the bloom-forming dinoflagellate Heterocapsa circularisquama and its infectious viruses, a field survey was conducted in Ago Bay, Japan, in 2001. A H. circularisquama bloom occurred in July. The bloom peaked in mid July and disintegrated within a few days at the end of July. The abundance of viruses infectious to $H$. circularisquama was high from the peak of the bloom and throughout the post-bloom period, but ceased by the end of August. At the peak of the bloom, $88 \%$ of the $H$. circularisquama cells in the population harbored small viruslike particles (VLPs). Based on transmission electron microscopic (TEM) observation, morphological resemblance between these VLPs and the single-stranded RNA (ssRNA) virus infecting $H$. circularisquama (HcRNAV: H. circularisquama RNA virus) isolated from the bloom was noticeable. The fluctuation patterns of the viruses indicated that at least 2 distinct types of virus with different host specificity spectra coexisted. A specific increase in viral abundance in the sediments was observed in the middle of the bloom, and these viruses were likely able to maintain their infectivity for at least 3 mo. The present study provides further evidence of the possible viral impacts on the biomass and clonal composition of algal populations in the natural environment, and offers support for the hypothesis that sediments are a reservoir of algal viruses.
\end{abstract}

KEY WORDS: Algal virus - ssRNA virus - Heterocapsa circularisquama - Population dynamics · Red tides · Harmful algal blooms

\section{INTRODUCTION}

Since the first reports on the high abundance of virus-like particles (VLPs) in natural seawater, several studies have highlighted their ecological significance (Bergh et al. 1989, Proctor \& Fuhrman 1990, Thingstad et al. 1993, Suttle 2000, Wommack \& Colwell 2000). Evidence indicating a possible relationship between viral infections and termination of some phytoplankton blooms has also accumulated. In particular, viral impacts on blooms of Emiliania huxleyi (Prymnesiophyceae) and Heterosigma akashiwo (Raphidophyceae) have been intensively studied. In both cases, bloom terminations were followed by specific in- creases in viral abundance, suggesting that viral infection is a significant factor regulating bloom dynamics (Bratbak et al. 1993, Nagasaki et al. 1994a,b, Brussaard et al. 1996, Tarutani et al. 2000). The objective of the present study was to examine the relationship between a microalga, Heterocapsa circularisquama (Dinophyceae), and viruses which infect it in the natural environment.

Heterocapsa circularisquama is a harmful bloomforming dinoflagellate that specifically kills bivalves (Horiguchi 1995), and is distributed on the west coast of Japan and Hong Kong (Tamai 1999, Iwataki et al. 2002). Since 1988, H. circularisquama blooms in Japan have frequently caused mass mortalities of bivalves 
such as the pearl oyster Pinctada fucata martensii, short-necked clam Ruditapes philippinarum, mussel Mytilus edulis, and oyster Crassostrea virginica (Nagai et al. 1996, Matsuyama 1999). Until 2002, more than 40 cases of $H$. circularisquama red tide have been recorded, including 18 incidences leading to fisheries damages (Matsuyama 2003). Ago Bay, the field area for the present survey, is an inlet dotted with small islands, and it is famous for its pearl oyster production ( USD 64 million $\mathrm{yr}^{-1}$ ). The first outbreak of a $\mathrm{H}$. circularisquama bloom in this bay was in August 1992. The maximum cell abundance during the bloom was 87420 cells $\mathrm{ml}^{-1}$, and 30 to $90 \%$ of cultured pearl oysters were damaged. Since then, H. circularisquama blooms occurred in this bay almost every year. The maximum abundances of $H$. circularisquama were 980, 55800, 5000, 20 000, 3580, 0.01, 3860 and 3056 cells ml ${ }^{-1}$ from 1993 to 2000, respectively, and serious damage to pearl oyster culture was also caused in 1994 and 1996 (Nakanishi et al. 1999, Tamai 1999, Matsuyama 2003). Indeed the abundance and the duration of $H$. circularisquama blooms in recent years in Ago Bay have been declining, but $H$. circularisquama is still regarded as one of the more noxious phytoplankton species which need to be vigilantly watched.

A large icosahedral double-stranded DNA (dsDNA) virus infecting Heterocapsa circularisquama (HcV) was the first dinoflagellate-infecting virus to be isolated and characterized (Tarutani et al. 2001, Nagasaki et al. 2003). Just recently, another small icosahedral ssRNA virus (HcRNAV) causing lysis of $H$. circularisquama has been isolated from the western part of Japan (Tomaru et al. 2004, this issue). As the algicidal activity of both viruses is highly specific to $H$. circularisquama, their possible control of its natural populations is suggested. However, no conclusive evidence of their impact has been obtained, as the ecological link between $H$. circularisquama and viruses in the natural environment has scarcely been elucidated so far. In the present paper, we report the dynamics of a $H$. circularisquama bloom and co-occurring viruses in Ago Bay in 2001, and discuss the possible relationship between them.

\section{MATERIALS AND METHODS}

Field survey and sampling. Field sampling was carried out at the Tategami Station in Ago Bay, Japan (Fig. 1), once a week from April through November 2001. This station is located in a semi-enclosed area in a water depth of ca. $10 \mathrm{~m}$. Pearl-oyster aquaculture is a major industry in the area. Water temperature, salinity, and dissolved oxygen concentration of the $0.5,5 \mathrm{~m}$ and bottom minus $1 \mathrm{~m}$ (B-1m) layers in the water column were measured by use of a Chlorotec Model ACL1150DK (Alec Electronics) and a dissolved oxygen meter, YSI Model 58, according to manufactures' recommendation, respectively. Simultaneously, seawater samples were collected from each layer using a Kitahara's water bottle $(1 \mathrm{l})$, and sediment samples $(0$ to $1 \mathrm{~cm}$ depth) were also collected using an Ekman-Birge bottom sampler equipped with a $36 \mathrm{~mm} \varnothing$ corer tube (Yokoyama \& Ueda 1997). They were immediately sent to the laboratory without fixation. Phytoplankton abundance was immediately assessed by direct counting with optical microscopy, and the titration of viruses infecting Heterocapsa circularisquama was carried out within $24 \mathrm{~h}$ of collection (see below). The sediment samples were stored at $10^{\circ} \mathrm{C}$ in the dark until titration in December 2001, i.e. 1 to 7 mo after collection. To evaluate the effect of storage to viral titer, both titration just after collection and re-titration after 7 mo storage

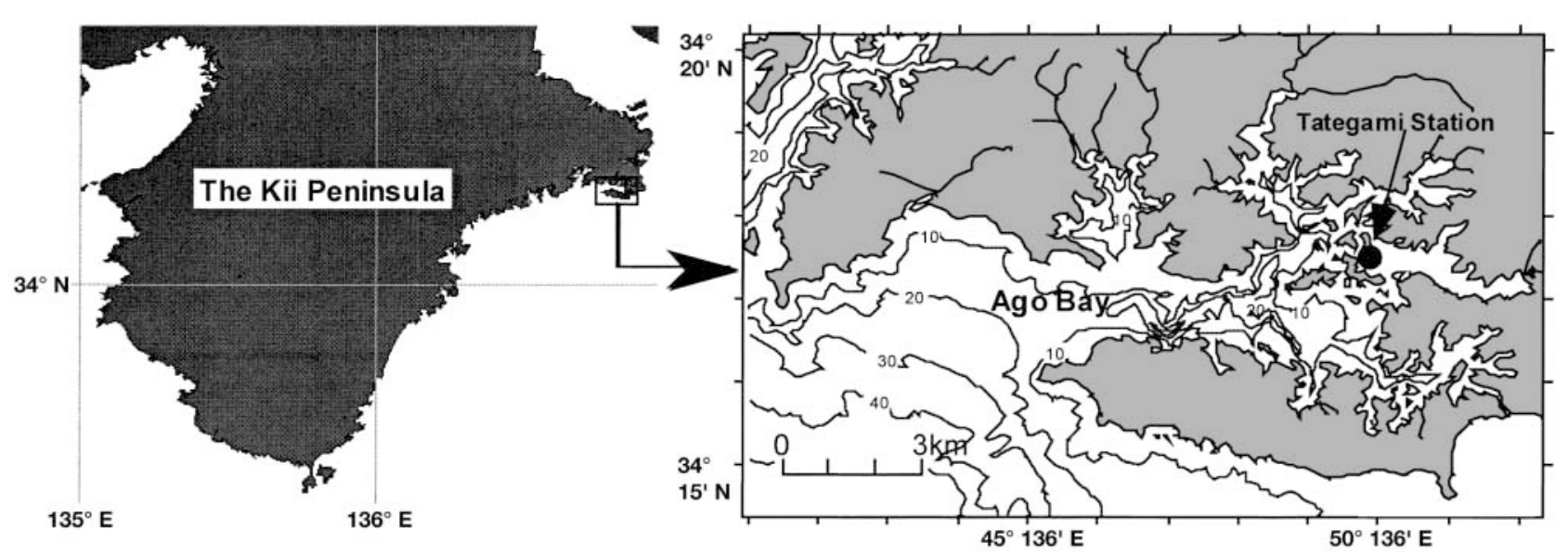

Fig. 1. Sampling station (Tategami Station;

) in Ago Bay, Mie Prefecture, Japan. In the detailed map (right), the depth contour line $(\mathrm{m})$ is also shown 
were conducted on a sediment sample collected on 5 August 2002 in Ago Bay.

Titration of viruses infecting Heterocapsa circularisquama. Before virus titration, seawater samples were prefiltered through $0.8 \mu \mathrm{m}$ pore-size polycarbonate membrane filters (Nuclepore) to remove zooplankton, phytoplankton, and most bacteria. Three grams of each sediment sample were shaken with $3 \mathrm{ml}$ of modified SWM3 medium (Chen et al. 1969, Itoh \& Imai 1987) enriched with $2 \mathrm{nM} \mathrm{Na}_{2} \mathrm{SeO}_{3}$ at $400 \mathrm{rpm}$ for 30 min, and centrifuged at $716 \times g$ for $10 \mathrm{~min}$ at $4^{\circ} \mathrm{C}$. The supernatant was filtered through a $0.2 \mu \mathrm{m}$ pore-sized Dismic-25cs filter (Advantec) to remove bacteria. The abundance of viruses infecting $H$. circularisquama in the seawater samples ( $5 \mathrm{~m}$ and B-1m) and the sediment samples was enumerated by means of the extinctiondilution method (Suttle 1993, Nagasaki \& Yamaguchi 1997). Briefly, filtrates were diluted with modified SWM3 medium in a series of 10 -fold dilution steps, and aliquots $(100 \mu \mathrm{l})$ of each dilution step were added to 8 wells in cell culture plates with 96 round-bottom wells (Falcon) containing $150 \mu \mathrm{l}$ of an exponentially growing host culture. As hosts, $H$. circularisquama strains HA92-1, HY9423, HU9433-P and HCLG-1 were used to enumerate viruses in the water samples, and HU9433-P and HCLG-1 were used to enumerate viruses in the sediment samples (Table 1). The cell culture plates were incubated under a 12:12 h light:dark cycle of 130 to $150 \mu \mathrm{mol}$ photons $\mathrm{m}^{-2} \mathrm{~s}^{-1}$ with cool white fluorescent illumination at $20^{\circ} \mathrm{C}$. The occurrence of algal lysis was then monitored every other day for 10 to $14 \mathrm{~d}$ by optical microscopy, and the most probable number of lytic viruses was calculated using the computer program designed by Nishihara et al. (1986). In the procedure, 8 viral clones from the sediment samples were obtained by 2 cycles of the extinction-dilution procedure (Nagasaki \& Yamaguchi 1997), using the same host strain of $H$. circularisquama that was initially used to obtain the pathogen. Their morphological features were examined by TEM as outlined below.

Transmission electron microscopy. Heterocapsa circularisquama cells from the seawater sample obtained from the B-1m layer on 16 July 2001 were examined by TEM according to the method described by Tarutani et al. (2001). Thin sections were stained with uranyl acetate and lead citrate, and then observed under a JEOL JEM-1010 TEM. The intracellular structure of natural cells was compared to that of exponentially growing cells incubated under a 12:12 h light:dark cycle of 130 to $150 \mu \mathrm{mol}$ photons $\mathrm{m}^{-2} \mathrm{~s}^{-1}$, with cool white fluorescent illumination at $20^{\circ} \mathrm{C}$. In the same way, thin sections of $H$. circularisquama cells at $2 \mathrm{~d}$ post-infection of the viruses from sediment samples and the negatively stained virus particles were also observed with TEM.

\section{RESULTS}

\section{Hydrographic data}

Hydrographic data collected at the Tategami Station are shown in Fig. 2. A Heterocapsa circularisquama bloom with a cell density of $10^{-1}$ to $\sim 10^{3}$ cells $\mathrm{ml}^{-1}$ occurred from 2 through 23 July (hereafter we define this as the bloom period), with bottom temperatures ranging from 20.5 to $22.8^{\circ} \mathrm{C}$, salinity 34.3 to $34.4 \mathrm{psu}$, and dissolved oxygen 3.6 to $4.3 \mathrm{mg} \mathrm{l}^{-1}$ (Fig. 2).

\section{Dynamics of Heterocapsa circularisquama and viruses in the water column}

The peak of Heterocapsa circularisquama abundance was in the B-1m layer on 16 July (2450 cells $\mathrm{ml}^{-1}$ ). Following the peak, $H$. circularisquama abundance rapidly decreased up to 30 July (Fig. 3A). During the survey, $H$. circularisquama cells were scarcely observed in the surface layer $(0.5 \mathrm{~m})$, and the cell abundance in the $5 \mathrm{~m}$ layer was 3 orders of magnitude lower than that of the B-1m layer at the peak of the bloom (16 July).

In the B-1m layer, viruses infecting Heterocapsa circularisquama strains HU9433-P and HA92-1

Table 1. Heterocapsa circularisquama. Strains used in the present experiments to enumerate the virus titer by means of the extinction-dilution method. All of them are axenic and clonal

\begin{tabular}{|lcc|}
\hline \multirow{2}{*}{ Strain } & Location & Origin \\
\cline { 2 - 3 } & & Isolation date \\
\hline H. circularisquama HU9433-Pa & Uranouchi Bay (Kochi Prefecture) & Dec 1994 \\
H. circularisquama HA92-1 & Ago Bay (Mie Prefecture) & Jun 1992 \\
H. circularisquama HCLG-1 & Gokasho Bay (Mie Prefecture) & Aug 1999 \\
H. circularisquama HY9423 & Yatsushiro Kai (Kumamoto Prefecture) & Sep 1994 \\
a Strain used to enumerate the lytic viruses in the sediment samples & \\
\end{tabular}



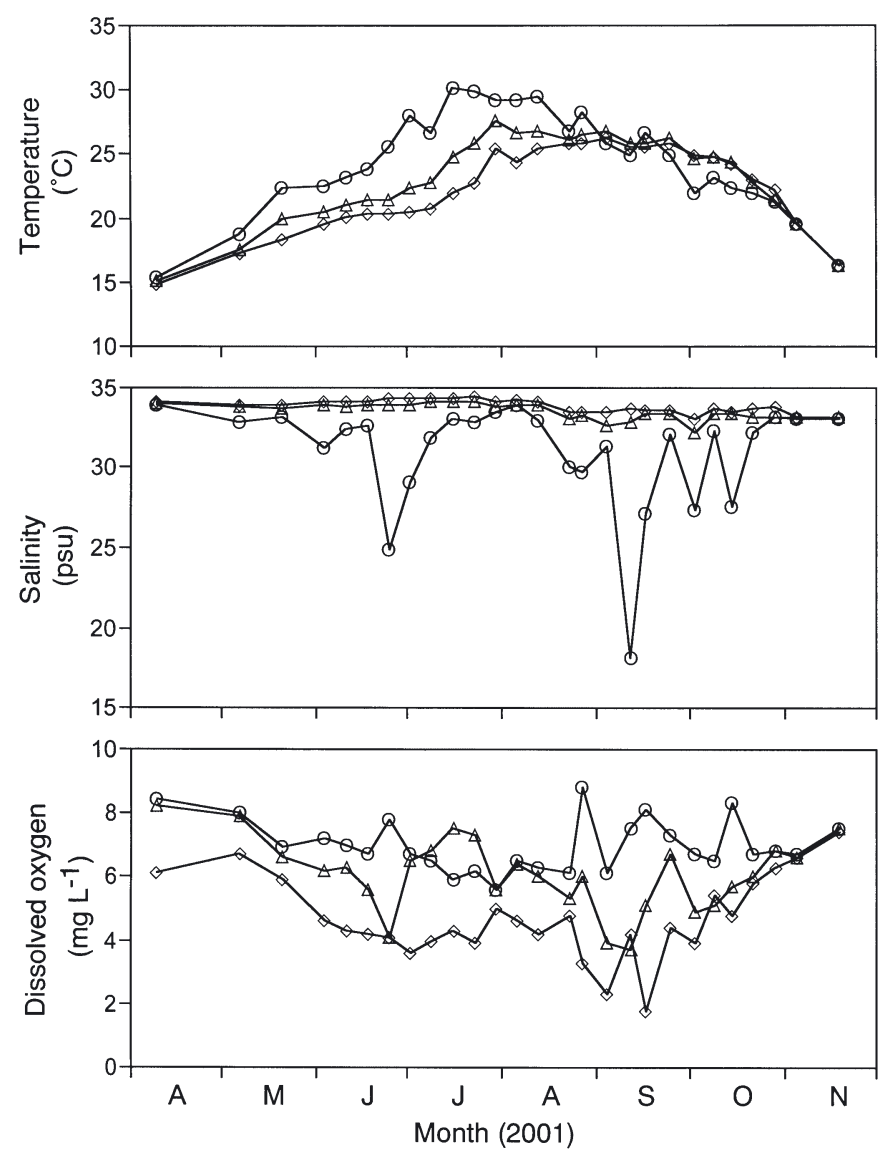

Fig. 2. Temporal changes in the hydrographic conditions in

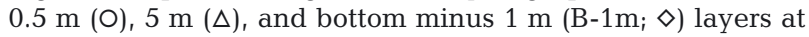
the Tategami Station during the field survey

showed similar trends in terms of dynamics, i.e. following a rapid increase from 16 through 23 July, they gradually decreased from 23 July to the end of August (Fig. 3C). Also in the $5 \mathrm{~m}$ layer, similar trends of dynamics were noticeable between them (Fig. 3B). Two different trends of fluctuation in virus abundance were observed through the survey using $4 \mathrm{H}$. circularisquama strains as hosts. At B-1m, the abundance of viruses infecting Strains HU9433-P and HA92-1 increased from 16 through 23 July and then gradually decreased to the end of August (Fig. 3C). The same decline was observed at $5 \mathrm{~m}$ (Fig 3B). Viruses infecting Strains HCLG-1 and HA92-1 also showed the same development, both at B-1m and $5 \mathrm{~m}$, but the decrease in abundance to $<0.1$ infectious unit $\mathrm{ml}^{-1}$ occurred 2 to $3 \mathrm{wk}$ earlier than for the viruses infectious to HU9433-P and HA92-1 (Fig. 3B,C).

In conjunction with the present study, 52 virus clones were isolated from the same water samples (Tomaru et al. 2004). However, no large dsDNA virus, such as $\mathrm{HcV}$ (Tarutani et al. 2001), was found among them.

\section{Viral dynamics in the sediments}

Fluctuation in viral titer of the sediment samples is shown in Fig. 3D. As a preliminary experiment revealed that storage at $10^{\circ} \mathrm{C}$ in the dark considerably affected the viral titer of sediment samples (93 to $98 \%$ decrease within $7 \mathrm{mo}$ ), this graph should be regarded as data reflecting an approximate trend in viral dynamics of the sediments, but not reflecting the absolute titers. The abundance of lytic viruses in the sediments showed a rapid increase during the Heterocapsa circularisquama bloom, from 16 through 23 July, and then gradually decreased from August through November (Fig. 3D).
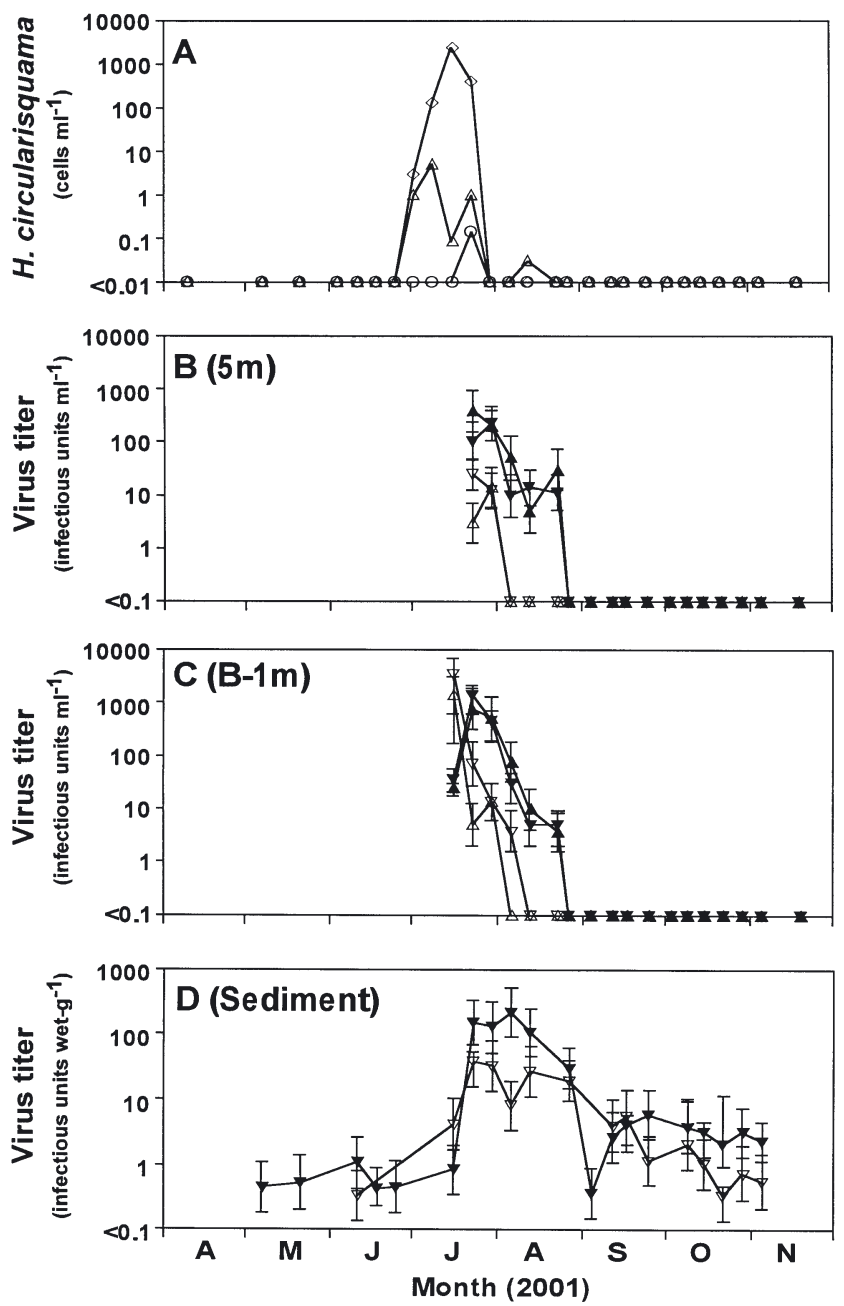

Fig. 3. Heterocapsa circularisquama. Temporal changes in the

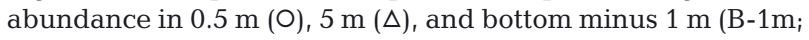
$\diamond$ ) layers at the Tategami Station (A), and the lytic viruses in $5 \mathrm{~m}$ layer (B), B-1m layer (C), and in the sediments (D). Abundance of viruses lytic to $H$. circularisquama was enumerated by the extinction-dilution method using the 4 typical host

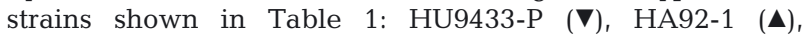
HCLG-1 $(\nabla)$, and HY9423 $(\Delta)$. Error bars are $95 \%$ CIs 


\section{TEM observations}

TEM observations revealed that the existence of small VLPs was restricted to the cytoplasm of the Heterocapsa circularisquama cells in the B-1m layer on 16 July (Fig. 4C,D), but no large HcV-like particles were detected. Small VLPs were detected in $88 \%$ of the thin sections of $H$. circularisquama ( $\mathrm{n}=202)$, and their distribution was restricted to within the cytoplasm. Although no crystalline array was observed, the VLPs were considered to be similar in appearance to the ssRNA virus HcRNAV simultaneously isolated from the same seawater sample (Tomaru et al. 2004). In addition, the intracellular structure of natural cells was remarkably different from that of vigorously growing cells incubated under suitable conditions, i.e. largely
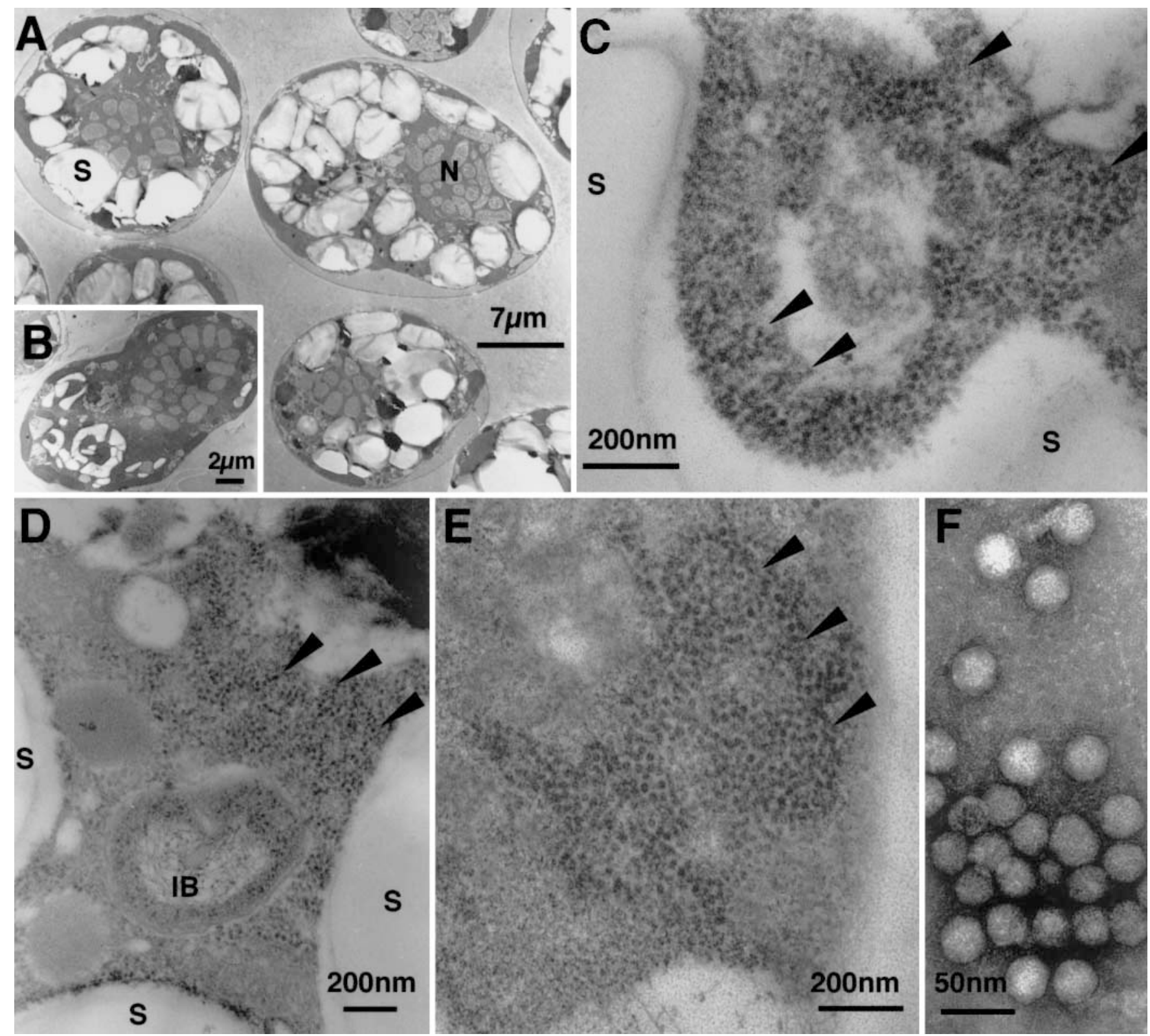

Fig. 4. Heterocapsa circularisquama. Transmission electron micrographs. (A) Cells from the natural population sampled from the bottom minus $1 \mathrm{~m}(\mathrm{~B}-1 \mathrm{~m})$ layer at the Tategami Station on 16 July 2001. For comparison with (A), a thin section of a vigorously growing cell incubated under suitable conditions (see 'Materials and methods') is shown (B). (C,D) Higher magnifications of virus-like particles randomly dispersed within the cytoplasm of $H$. circularisquama cells in (A) (arrowheads). (E) Aggregation of viruses within the cytoplasm of a $H$. circularisquama cell infected with a HcRNAV-like virus isolated from the sediment sample, and (F) negatively stained virus-like particles (VLPs) in the suspension of (E). $\mathrm{S}=$ starch grain, $\mathrm{N}=$ nucleus, IB = intracellular bacterium 
occupied with vacuoles filled with an electron-lucent material (Fig. 4A), which are likely starch grains (Horiguchi 1995). In contrast, vigorously growing cells contained a smaller number of vacuoles (Fig. 4B).

Viruses isolated from the sediment samples were icosahedral and $31 \pm 2 \mathrm{~nm}$ (mean $\pm \mathrm{SD}, \mathrm{n}=30$ ) in diameter, and formed random aggregations in the cytoplasm of Heterocapsa circularisquama; thus, they are considered to be morphologically similar to HcRNAV (Fig. 4E,F).

\section{DISCUSSION}

In the present survey, as virus titration of the water samples was not started until the peak of the bloom (Fig. 3B,C), viral dynamics before this time are unknown. However, considering that viral abundance in the water column was less than the detectable limit after September when host cells were not observed in the water column, it is presumable that the viral titer in the water column was low before the bloom and increased during the bloom period in July (Fig. 3). This conjecture was also supported by the results obtained through the field survey in 2002 at the same sampling station, in which viruses infecting Heterocapsa circularisquama were scarcely detected before the bloom, but showed a specific increase in its early stage (Tomaru et al. unpubl. data). Thus, a possible relationship between $H$. circularisquama and viruses was suggested: emergence of viruses in the bloom period, both in the water column and the sediments, most probably reflected the results of viral lysis of $H$. circularisquama cells (Fig. 3). The observation that a large proportion (88\%) of $H$. circularisquama cells harbored VLPs (i.e. most likely infected by HcRNAV-like viruses) also strengthens the above speculation. In laboratory experiments, $H$. circularisquama cells infected by HcRNAV markedly lost their motility (Tomaru et al. 2004). Thus, it is likely that virus-infected $H$. circularisquama cells had sunk down to the bottom layer and sediments during the bloom, and then burst to supply newly produced viruses to the environment.

In conjunction with the present survey, only small types of virus were isolated by means of the extinctiondilution method from natural waters and sediments (Tomaru et al. 2004). By this method, the most abundant types of virus lytic to a Heterocapsa circularisquama strain (used as a host) tend to be selected and isolated more frequently, because viruses were picked up from the most diluted wells in the isolation procedure. The reason why no large viruses such as $\mathrm{HcV}$ were isolated might be due to the dominance of the HcRNAV-like virus. Another point to consider is that large virus particles were not detected in thin sections of $H$. circularisquama at the peak of the bloom either. As for the viruses isolated from the sediments, they were also morphologically similar to those isolated from the water samples (Fig. 4E,F). Therefore, we consider that the small viruses were more abundant than the large ones in the present bloom.

Because high abundance of lytic viruses was detected in the sediments even after the viruses in the water column disappeared in August, they may be longer lived than in the water column once they are buried in the sediment. Based on the results of titration (Fig. 3D), it is probable that viruses remained infective in the sediments for more than $3 \mathrm{mo}$. These results are comparable to those of Lawrence et al. (2002), who detected viral agents lysing Heterosigma akashiwo as deep as $40 \mathrm{~cm}$ below the sediment-water interface. Considering that 93 to $98 \%$ of the viral titer was lost within $7 \mathrm{mo}$ of storage at $10^{\circ} \mathrm{C}$ in the dark, the gradual decrease in virus titer in the sediments from August through November (Fig. 3D) might have been caused by the inactivation of viruses, i.e. loss of infectivity. Resuspension is also a possible explanation for the decrease in virus abundance in the sediments, but the low values found in the water above the sediment (B$1 \mathrm{~m})$ do not support this hypothesis.

Another noticeable point is that 2 apparently different trends in fluctuation of viral abundance were observed in the water column by using 4 Heterocapsa circularisquama strains as hosts in the survey (Fig. 3B,C). This suggests that there were 2 distinct types of viruses having different host specificity spectra; one is infectious to HU9433-P and HA92-1 (UA-type), and the other to HCLG-1 and HY9423 (CY-type). They were also detected in the sediments (Fig. 3D). These results agree well with the observation that HcRNAV strains isolated from western Japan were divided into 2 types (UA and CY types) based on their infection spectra (Tomaru et al. 2004). The infection specificity of each type of HcRNAV was strain-specific, and complementarily different to one other, i.e. UA-type viruses were lytic to some of the $H$. circularisquama strains, but not to those that were sensitive to CY-type viruses, and vice versa. Among $4 \mathrm{H}$. circularisquama strains isolated from the bloom (HCAG-2 to 5), 3 (HCAG-2, -3 and -4) were specifically sensitive to the CY-type virus, and 1 (HCAG-5) was specifically sensitive to the UAtype virus (Tomaru et al. 2004). Thus, because the distinct types of virus and host coexisted in the environments, it is probable that the dynamics of each type of virus reflected the dynamics of its respective host, and the 2 types of virus play a significant role in regulating the intra-species diversity as well as the biomass of $H$. circularisquama populations in the natural environment. Indeed, these observations do not completely rule out the possibility of simultaneous infection by the 
2 types of virus, but $H$. circularisquama clones having apparent sensitivity to both types of virus were not isolated $(\mathrm{n}=56)$. Hence, even though $H$. circularisquama clones sensitive to both types of virus had coexisted, it is unlikely that they were dominant in the population. Of course, the sensitivity spectrum of each host clone should be translated with care, as the effects of growth and physiological condition of hosts on their susceptibility to viruses was barely examined.

Physical conditions, nutrient conditions, and impacts by grazers are also considered to be important factors regulating algal blooms, but these factors were not examined sufficiently in the present survey. Physical parameters (temperature, salinity, and dissolved oxygen concentration) did not show any significant changes in the duration of the Heterocapsa circularisquama bloom (Fig. 2), which were in a suitable range for the growth of $H$. circularisquama (Yamaguchi et al. 1997, Nakanishi et al. 1999). With regard to nutrients in the bottom layer, concentrations of both dissolved inorganic nitrogen $(\mathrm{N})$ and phosphate $(\mathrm{P})$ ranged at a relatively low level: 0.16 to 0.52 and 0.03 to $0.13 \mu \mathrm{M}$, respectively (K. Nakanishi et al. unpubl. data). Thus, low nutrient conditions are considered to be another significant factor affecting the dynamics of the bloom. Although it is unknown what caused the apparent difference in intracellular structures between the natural cells observed at the peak of the bloom and vigorously growing cells in culture (Fig. 3A,B), one possible explanation is the physiological effects of the low nutrient condition, as HcRNAV-infected cells did not show the similar intracellular feature (i.e. maximizing of vacuoles) in laboratory experiments (Tomaru et al. 2004). Because the abundance of zooplankton was not monitored in the present survey, the grazing impact on the $H$. circularisquama population is unknown. Thus, only based on the present results, it is difficult to assess the extent of contribution of each factor in regulating the bloom dynamics and causing the bloom termination.

Nevertheless, the present study provides further evidence for the possible viral impact on the biomass and clonal composition of algal populations in the natural environment, and supports the hypothesis given by Tarutani et al. (2000): viruses are an important component in quantitatively and qualitatively controlling phytoplankton populations. Because up to $88 \%$ of the Heterocapsa circularisquama cells in the population contained VLPs in their cytoplasm, the impact of viral infection was considered exceedingly high compared to the cases of other algal viruses reported so far (Bratbak et al. 1993, Nagasaki et al. 1994a,b, Brussaard et al. 1996, Gastrich et al. 2002). The results of our field survey and the intra-species host range assay given by Tomaru et al. (2004) suggest that 2 possibly indepen- dent host-virus systems were involved in the $H$. circularisquama bloom. To provide direct evidence of the viral impacts on host clonal composition, however, molecular probing techniques would be required to identify different types of host and to distinguish infection by different types of virus. The present study also offers support for the hypothesis that sediments are a reservoir of viruses (Lawrence et al. 2002). The presence of HcRNAV-like viruses in sediments provides indirect evidence that viral infection of $H$. circularisquama occurs in overlying waters. However, processes of viral recruitment into sediments, and viral release (resuspension) from sediments, have not been elucidated yet. Our present results will invite further investigation into this area in the future.

Acknowledgements. This study was supported by the Industrial Technology Research Grant Program in 2001 from the New Energy and Industrial Technology Development Organization of Japan (NEDO), the Society for Techno-innovation of Agriculture, Forestry and Fisheries (STAFF), and the Ministry of Agriculture, Forestry and Fisheries, Japan. We are grateful to Dr. T. Uchida of the Hokkaido National Fisheries Research Institute, Japan, Dr. Y. Matsuyama of the National Research Institute of Fisheries and Environment of Inland Sea, Japan, and Dr. I. Imai of Kyoto University, Japan, who kindly provided Heterocapsa circularisquama strains.

\section{LITERATURE CITED}

Bergh Ø, Børsheim KY, Bratbak G, Heldal M (1989) High abundance of viruses found in aquatic environments. Nature 340:467-468

Bratbak G, Egge JK, Heldal M (1993) Viral mortality of the marine alga Emiliania huxleyi (Haptophyceae) and termination of algal blooms. Mar Ecol Prog Ser 93:39-48

Brussaard CPD, Kempers RS, Kop AJ, Riegman R, Heldal M (1996) Virus-like particles in a summer bloom of Emiliania huxleyi in the North Sea. Aquat Microb Ecol 10:105-113

Chen LCM, Edelstein T, McLachlan J (1969) Bonnemaisonia hamifera Hariot in nature and in culture. J Phycol 5: 211-220

Gastrich MD, Anderson OR, Cosper EM (2002) Virus-like particles (VLPs) in the alga, Aureococcus anophagefferens (Pelagophyceae), during 1999-2000 brown tide blooms in Little Egg Harbor, New Jersey. Estuaries 25:938-943

Horiguchi T (1995) Heterocapsa circularisquama sp. nov. (Peridinales, Dinophyceae): a new marine dinoflagellate causing mass mortality of bivalves in Japan. Phycol Res 43:129-136

Itoh K, Imai I (1987) Raphidophyceae. In: Japan Fisheries Resource Conservation Association (ed). A guide for studies of red tide organisms. Shuwa, Tokyo, p 122-130 (in Japanese)

Iwataki M, Wong MW, Fukuyo Y (2002) New record of Heterocapsa circularisquama (Dinophyceae) from Hong Kong. Fish Sci 68:1161-1163

Lawrence JE, Chan AM, Suttle CA (2002) Viruses causing lysis of the toxic bloom-forming alga Heterosigma akashiwo (Raphidophyceae) are widespread in coastal sediments of British Columbia, Canada. Limnol Oceanogr $47: 545-550$ 
Matsuyama Y (1999) Harmful effect of dinoflagellate Heterocapsa circularisquama on shellfish aquaculture in Japan. Jpn Agric Res Q 33:283-293

Matsuyama Y (2003) Physiological and ecological studies on harmful dinoflagellate Heterocapsa circularisquama-I. Elucidation of environmental factors underlying the occurrence and development of $H$. circularisquama red tide. Bull Fish Res Agency 7:24-105 (in Japanese with English abstract)

Nagai K, Matsuyama Y, Uchida T, Yamaguchi M, Ishimura M, Nishimura A, Akamatsu S, Honjo T (1996) Toxicity and $\mathrm{LD}_{50}$ levels of the red tide dinoflagellate Heterocapsa circularisquama on juvenile pearl oysters. Aquaculture 144:149-154

Nagasaki K, Yamaguchi M (1997) Isolation of a virus infectious to the harmful bloom causing microalga Heterosigma akashiwo (Raphidophyceae). Aquat Microb Ecol 13: 135-140

Nagasaki K, Ando M, Imai I, Itakura S, Ishida Y (1994a) Viruslike particles in Heterosigma akashiwo (Raphidophyceae); a possible red tide disintegration mechanism. Mar Biol 119:307-312

Nagasaki K, Ando M, Itakura S, Imai I, Ishida Y (1994b) Viral mortality in the final stage of Heterosigma akashiwo (Raphidophyceae) red tide. J Plankton Res 16:1595-1599

Nagasaki K, Tomaru Y, Tarutani K, Katanozaka N, Yamanaka S, Tanabe H, Yamaguchi M (2003) Growth characteristics and intra-species host specificity of a large virus infecting the dinoflagellate Heterocapsa circularisquama. Appl Environ Microbiol 69:2580-2586

Nakanishi K, Onaka S, Kobayashi T, Masuda T (1999) Bloom dynamics of Heterocapsa circularisquama in Ago Bay, Japan. Bull Plankton Soc Jpn 46:161-164 (in Japanese)

Nishihara T, Kurano N, Shinoda S (1986) Calculation of most probable number for enumeration of bacteria on a microcomputer. Eisei Kagaku 32:226-228 (in Japanese)

Proctor LM, Fuhrman JA (1990) A viral mortality of marine bacteria and cyanobacteria. Nature 343:60-62

Editorial responsibility: Gunnar Bratbak, Bergen, Norway
Suttle CA (1993) Enumeration and isolation of viruses. In: Kemp PF, Sherr BF, Sherr EF, Cole JJ (eds) Current methods in aquatic microbial ecology. Lewis Publishers, Boca Raton, FL, p 121-134

Suttle CA (2000) The ecological, evolutionary and geochemical consequences of viral infection of cyanobacteria and eukaryotic algae. In: Hurst CJ (ed) Viral ecology. Academic Press, London, p 247-296

Tamai K (1999) Current status of outbreaks and fisheries damages due to Heterocapsa circularisquama. Bull Plankton Soc Jpn 46:153-154 (in Japanese)

Tarutani K, Nagasaki K, Yamaguchi M (2000) Viral impacts on total abundance and clonal composition of the harmful bloom-forming phytoplankton Heterosigma akashiwo. Appl Environ Microbiol 66:4916-4920

Tarutani K, Nagasaki K, Itakura S, Yamaguchi M (2001) Isolation of a virus infecting the novel shellfish-killing dinoflagellate Heterocapsa circularisquama. Aquat Microb Ecol 23:103-111

Thingstad TF, Heldal M, Bratbak G, Dundas I (1993) Are viruses important partners in pelagic food webs? Trends Ecol Evol 8:209-213

Tomaru Y, Katanozaka N, Nishida K, Shirai Y, Tarutani K, Yamaguchi M, Nagasaki K (2004) Isolation and characterization of two distinct types of HcRNAV, a singlestranded RNA virus infecting the bivalve-killing microalga Heterocapsa circularisquama. Aquat Microb Ecol 34: 207-218

Wommack KE, Colwell RR (2000) Virioplankton: viruses in aquatic ecosystems. Microbiol Mol Biol Rev 64:69-114

Yamaguchi M, Itakura S, Nagasaki K, Matsuyama Y, Uchida T, Imai I (1997) Effects of temperature and salinity on the growth of the red tide flagellate Heterocapsa circularisquama (Dinophyceae) and Chattonella verruculosa (Raphidophyceae). J Plankton Res 19:1167-1174

Yokoyama K, Ueda H (1997) A simple corer set inside an Ekman grab to sample intact sediments with the overlying water. Benthos Res 52:119-122

Submitted: March 17, 2003; Accepted: August 22, 2003 Proofs received from author(s): February 10, 2004 